\title{
The influence of silica functionalized with silanes on migration of heavy metals in soil
}

\author{
Piotr Grzesiak $^{1 *}$, Joanna Łukaszyk ${ }^{1}$, Elżbieta Gabała ${ }^{2}$, Joanna Kurczewska, Grzegorz Schroeder \\ ${ }^{1}$ Institute of Plant Protection - National Research Institute, Department of Ecology and Environmental Protection, \\ Wtadystawa Wegorka 20, 60-318 Poznań, Poland \\ ${ }^{2}$ Institute of Plant Protection - National Research Institute, The Research Centre of Quarantine, Invasive and Genetically \\ Modified Organisms, Władystawa Wegorka 20, 60-318 Poznań, Poland \\ ${ }^{3}$ Adam Mickiewicz University in Poznań, Faculty of Chemistry, Umultowska 89b, 61-614 Poznań, Poland \\ "Corresponding author: e-mail: Grzesiak@iorpib.poznan.pl
}

\begin{abstract}
3-Mercaptopropyl-trimethoxysilane and [3-(2-aminoethylamino)propyl]trimethoxysilane were used to functionalize the surface of silica from Piotrowice in Poland to stabilize heavy metals (HMs) and arsenic in soil. The soil for the study was sampled from the impact zone of Głogów Copper Smelter and Refinery. The soil samples were exposed to five-step Tessier sequential extraction. The speciation studies were limited to five sequentially defined fractions in which metal content was determined. The addition of unmodified silica did not affect significantly the concentration of metals in individual fractions. Significant changes were noted upon introduction of functionalized silica in the soil. The hybrid formulations obtained significantly reduce the release of heavy metals and arsenic from soil sorption complex. The results indicate the potential use of functional formulations for reduction of metal migration in soil in the areas of exceeded concentration of heavy metals and arsenic in the soil, caused by industrial activity.
\end{abstract}

Keywords: functionalized silica, heavy metals, Soil stabilization.

\section{INTRODUCTION}

The bioavailable fraction of soil solution contains many nutrients important for plant growth. Among the microand macro-elements there are also metals. The metals are divided into two groups: those necessary for the functioning of plant cells (such as $\mathrm{Fe}, \mathrm{Cu}, \mathrm{Mn}, \mathrm{Co}, \mathrm{Zn}$, $\mathrm{Ni}$ ) and those that are unnecessary for them (e.g. Cd, Hg, $\mathrm{Pb}, \mathrm{Cr})^{1-5}$. Both, an excess (toxic dose) and a deficit of these metals (plant stress) are harmful to plants. Changes in the content and availability of metals in soil depend on many factors including human activities, because the main sources of heavy metal impurities are non-ferrous metal smelters, mines, fertilizers and fungicides ${ }^{2,6,7}$. It is well known that only some metals from soil are easily accessible to plants. The efficiency of metal absorption by plant cells depends on: the form of the trace metal, substrate $\mathrm{pH}$, organic matter content in the substrate and the concentration of other ions ${ }^{7}$. Thus the ability to absorb metals from soil depends strongly on the type of tillage by farmers and the substances deliberately introduced into soil that affect the bioavailability of metals in amounts necessary for the plants. One of the most important factors determining the mobility of metals in soil is $\mathrm{pH}$ value of the substrate. The bioavailability of most metals increases with decreasing $\mathrm{pH}$. One of the methods of restricting migration of metals in soil is an addition of a substance permanently binding metals ions to the substrate.

Hybrid inorganic-organic materials based on silica and silanes can be used for this purpose. The systems having a monoamine ligand can be suitable for removal of cooper, zinc or cadmium ${ }^{8}$ while the one with thiol functional groups - for mercury 9 . A bifunctional sorbent, with amine and thiol groups, can be applied for removal of different ions, like $\mathrm{Cr}, \mathrm{Fe}, \mathrm{Mn}, \mathrm{Pd}^{\mathbf{1 0}, 11}$. Previously we have worked with different types of inorganic supports such as silica, quartz sand or magnetic matrices ${ }^{12-18}$. The surfaces of these materials were functionalized with variety of organic compounds depending on a desired application of such a system. Previously obtained hybrid materials were designed to remove different heavy metals from aqueous solutions and soil. All our materials were characterized by high efficiency and stability. This paper presents result of the studies concerning the influence of silica from the mine in Piotrowice (Poland) functionalized with silanes and non-functionalized on metal assimilation by plants, based on analysis of extracts obtained by sequential Tessier method ${ }^{19}$. The selection of silica was determined by the material availability and the cost of the final product applied for limiting of metal ion migration in soil and their bioavailability. The use of a bifunctional material, carrying two different functional groups, should improve the effectiveness of binding of different pollutants simultaneously.

\section{EXPERIMENTAL}

\section{Material and methods}

Silica used was purchased from Polish mine Piotrowice (Zakłady Przetwórstwa Surowców Chemicznych i Mineralnych „Piotrowice” Sp. z o.o.). Silanes, 3-Mercaptopropyltrimethoxysilane; $\left(\mathrm{CH}_{3} \mathrm{O}\right)_{3} \mathrm{Si}\left(\mathrm{CH}_{2}\right)_{3} \mathrm{SH}$ (I) and 3-[2-(2-Aminoethylamino)ethylamino]propyltrimethoxysilane; $\left(\mathrm{CH}_{3} \mathrm{O}\right)_{3} \mathrm{Si}\left(\mathrm{CH}_{2}\right)_{3} \mathrm{NH}\left(\mathrm{CH}_{2}\right)_{2} \mathrm{NH}\left(\mathrm{CH}_{2}\right)_{2} \mathrm{NH}_{2}$ (II) were commercial products of Aldrich. Hydrochloric acid and ethanol were purchased from POCH (Poland). All the chemicals were of analytical grade.

The particle size of the silica substrate was determined by laser technique MicroTec 22 Plus (Fritsch GmbH). The porosity of the silica substrate was determined by mercury porosimeter: Pascal 140 and 240 with Software Pascal 140/240 Ver. 1.05 from Thermo Electron.

The infrared spectra were taken on an IFS 66v/s Fourier transform infrared (FTIR) spectrophotometer from Bruker, equipped with an MCT detector (125 scans, resolution $\left.2 \mathrm{~cm}^{-1}\right)$. The spectra were recorded in the 
$400-4000 \mathrm{~cm}^{-1}$ range for $\mathrm{KBr}$ pellets. Elemental analysis of the supports studied was carried out on a Vario ELIII (Elementar) analyzer. The presence of elements in the functionalized materials was confirmed using an X-ray fluorescence (XRF) spectrometer (MiniPal) from Philips.

Surface morphology of the silica materials was studied by a Hitachi S3000N scanning electron microscope, SEM (magnification 15000-100000x; secondary electron SE and backscatter electron BSE detectors). Transmission electron microscope (TEM) images were recorded on a Hitachi HT7700 microscope, operating at accelerating voltage of $100 \mathrm{kV}$. They were used to monitor the morphology and structural properties of all samples, as well as for elemental analysis with the help of energy dispersive X-ray spectroscopy EDS/TEM. The material to be studied was deposited on nickel grids coated with a carbon film.

The content of heavy metals $(\mathrm{Cu}, \mathrm{Pb}, \mathrm{Zn}, \mathrm{Cd})$ in the extracts was determined by the flame absorption spectroscopy, while that of arsenic was assessed by the hydride generation technique using sodium bromide and hydrochloric acid. Atomic absorption spectrometer, ASA (Varian GTA120) was used for determination of metal concentration according to the methodology of FAAS and ETAAS line with the PCA accreditation No. AB 1281 (Methodology for determination of heavy metals in soil samples. The materials of certified Environmental Analysis Laboratory IOR-PIB, Poland).

\section{A procedure of silica surface functionalization by silanes}

A sample of $100 \mathrm{~g}$ of silica was mixed with $200 \mathrm{ml}$ of $5 \mathrm{~mol} \mathrm{dm}^{-3}$ hydrochloric acid water solution, and then washed and dried. The silica was functionalized by a mixture of silanes (I) and (II) (1:1) in ethanol, using different amounts of silanes per gram of silica in order to obtain the silica functionalized with $1 \%$ or $5 \%$ of silanes. The process of functionalization of silica was completed in $48 \mathrm{~h}$. After solvent evaporation the hybrid material was obtained.

\section{A procedure for metal extraction from soil samples}

The soil for the study was sampled from the impact zone of Głogów Copper Smelter and Refinery. The soil was screened in order to remove solid impurities, and dried at $105^{\circ} \mathrm{C}$ to constant weight (soil moisture content below $0.5 \%$ ). In the dried and ground soil the total content of heavy metals and arsenic was determined by atomic absorption spectroscopy (AAS) after extraction with $65 \% \mathrm{HNO}_{3}$. The effectiveness of binding of heavy metals and arsenic by the functionalized silica was studied. In the weighed reactor $50.0 \pm 0.1 \mathrm{~g}$ of soil (14 samples) was introduced, followed by an addition of an appropriate amount ( 2 or $5 \mathrm{~g}$ ) of the non-functionalized and functionalized silica and $25 \mathrm{~mL}$ of water, and the contents were left for 4 or 30 days. The reference sample without silica was also prepared ("0" sample). The samples were mixed every day and the moisture content was maintained constant. The soil samples were exposed to five-step Tessier sequential extraction, using for the same soil sample increasingly stronger extractants (Table 1). The speciation studies were limited to five sequentially defined fractions in which metal content was determined. In brief, the fifth fraction of this method consists of metals bound with alumionosilicates. This fraction is unavailable for plants because it requires radical agents $\left(10 \mathrm{M} \mathrm{HNO}_{3}\right.$ at boiling point) for the release of metals.

For the sequence analysis a portion of $1.000 \pm 0.001 \mathrm{~g}$ of the soil sample was weighted. Individual steps of extraction were carried out in glass centrifuge tubes of $50 \mathrm{ml}$. The solution acidity was stabilized at each stages of the extraction process according to the methodology. The samples were shaken in a horizontal shaker with a thermostatic water bath having programmable temperature range from $20^{\circ} \mathrm{C}$ to $100^{\circ} \mathrm{C}$ (an accuracy of $\pm 2^{\circ} \mathrm{C}$ ). After each extraction step, the samples were centrifuged for 30 minutes. The supernatant was transferred to a calibrated polypropylene tube with a hermetic seal. The residual precipitate in a centrifuge tube was washed with demineralized water $(5 \mathrm{ml})$, centrifuged again for 30 minutes. The washings were pipetted and combined with the first portion of the extract. The content of heavy metals and arsenic in the solutions was determined. The experiments were repeated three times for each reactor and the average values were taken. The solutions derived from the first three stages of extraction were acidified with four drops of concentrated nitric $\operatorname{acid}(\mathrm{V})$.

\section{RESULTS AND DISCUSSION}

\section{Characterization of the materials studied}

The silica was characterized by various physico-chemical techniques. The inorganic material from Piotrowice was described by the following parameters: total pore volume $2.74 \mathrm{~cm}^{3} \mathrm{~g}^{-1}$, total surface area $5.48 \mathrm{~m}^{2} \mathrm{~g}^{-1}$, average pore radius $31.97 \mu \mathrm{m}$, total porosity $131.8 \%$, apparent density $0.48 \mathrm{~g} \mathrm{~cm}^{-3}$. The low surface area of raw silica will probably affect very limited sorption properties of the material. The SEM images of the material studied before and after functionalization with the silanes are shown in Figure 1. The material is not homogenous and consists of particles of the size ranging from 1 to $50 \mu \mathrm{m}$. After the surface functionalization, the shape of

Table 1. The methods of extraction and forms of occurrence of heavy metals in soil

\begin{tabular}{|c|c|c|}
\hline Fraction & Form of metal & Extraction method \\
\hline $\mathrm{F}_{1}$ & Exchangeable metals & $10 \mathrm{~cm}^{3} 1 \mathrm{M} \mathrm{CH}_{3} \mathrm{COONH}_{4}(\mathrm{pH} 7.0)$, shaking time $1 \mathrm{~h}$, temp. $20^{\circ} \mathrm{C}$ \\
\hline $\mathrm{F}_{2}$ & Metals bound to carbonates & $\begin{array}{l}20 \mathrm{~cm}^{3} 1 \mathrm{M} \mathrm{CH}_{3} \mathrm{COONa} \text { acidified with } \mathrm{CH}_{3} \mathrm{COOH} \text { to } \mathrm{pH} 5.0 \text {, shaking time } 5 \mathrm{~h} \text {, temp. } \\
20^{\circ} \mathrm{C}\end{array}$ \\
\hline $\mathrm{F}_{3}$ & $\begin{array}{l}\text { Metals bound to iron and manganese } \\
\text { oxides }\end{array}$ & $20 \mathrm{~cm}^{3} 0.04 \mathrm{M} \mathrm{NH}_{2} \mathrm{OH}^{*} \mathrm{HCl}$ soluble in $25 \% \mathrm{CH}_{3} \mathrm{COOH}$, shaking time $5 \mathrm{~h}$, temp. $95^{\circ} \mathrm{C}$ \\
\hline $\mathrm{F}_{4}$ & Metals bound to organic matter & $\begin{array}{l}5 \mathrm{~cm}^{3} 0.02 \mathrm{M} \mathrm{HNO}_{3}+5 \mathrm{~cm}^{3} 30 \% \mathrm{H}_{2} \mathrm{O}_{2}(\mathrm{pH} 2.0) \text {, shaking time } 2 \mathrm{~h} \text {, temp. } 85^{\circ} \mathrm{C} \\
5 \mathrm{~cm}^{3} 30 \% \mathrm{H}_{2} \mathrm{O}_{2}(\mathrm{pH} 2.0) \text {, shaking time } 3 \mathrm{~h} \text {, temp. } 85^{\circ} \mathrm{C} \\
10 \mathrm{~cm}^{3} 3.2 \mathrm{M} \mathrm{CH}_{3} \mathrm{COONH}_{4} \text { in } 20 \% \mathrm{HNO}_{3} \text {, shaking time } 0.5 \mathrm{~h} \text {, temp. } 20^{\circ} \mathrm{C}\end{array}$ \\
\hline $\mathrm{F}_{5}$ & Metals bound to aluminosilicates & $\begin{array}{l}3 \mathrm{~cm}^{3} 10 \mathrm{M} \mathrm{HNO}_{3}+3 \times 2 \mathrm{~cm}^{3} \mathrm{H}_{2} \mathrm{O}_{2} \text {, shaking time } 1 \mathrm{~h}+10 \mathrm{~cm}^{3} \mathrm{H}_{2} \mathrm{O} \text {, shaking time } 0.5 \mathrm{~h} \text {, } \\
\text { boiling temp. }\end{array}$ \\
\hline
\end{tabular}




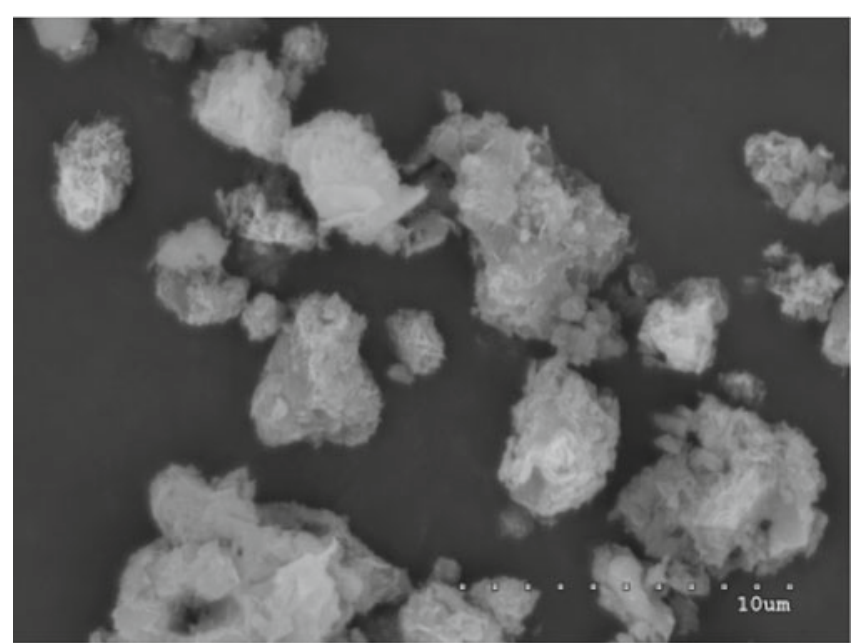

a

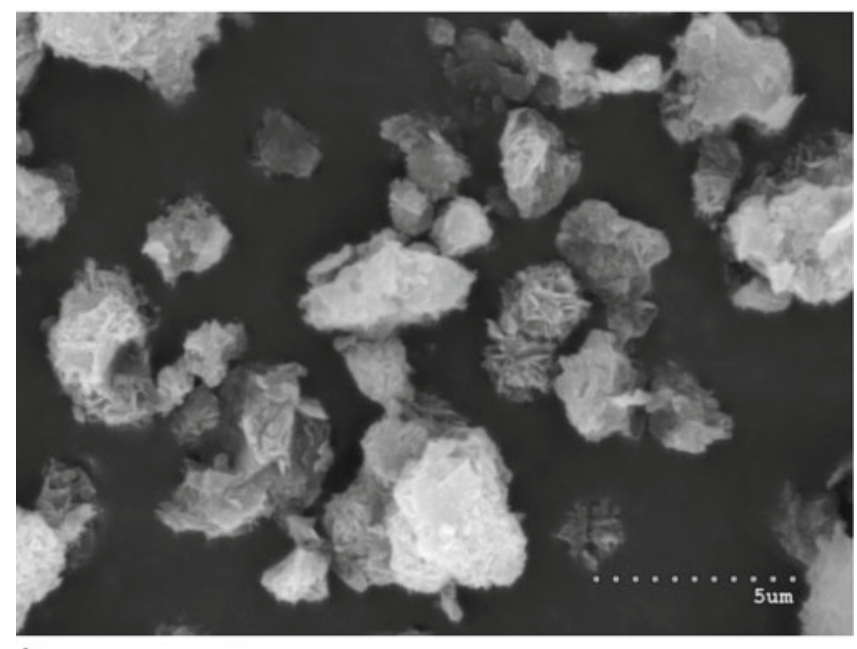

b

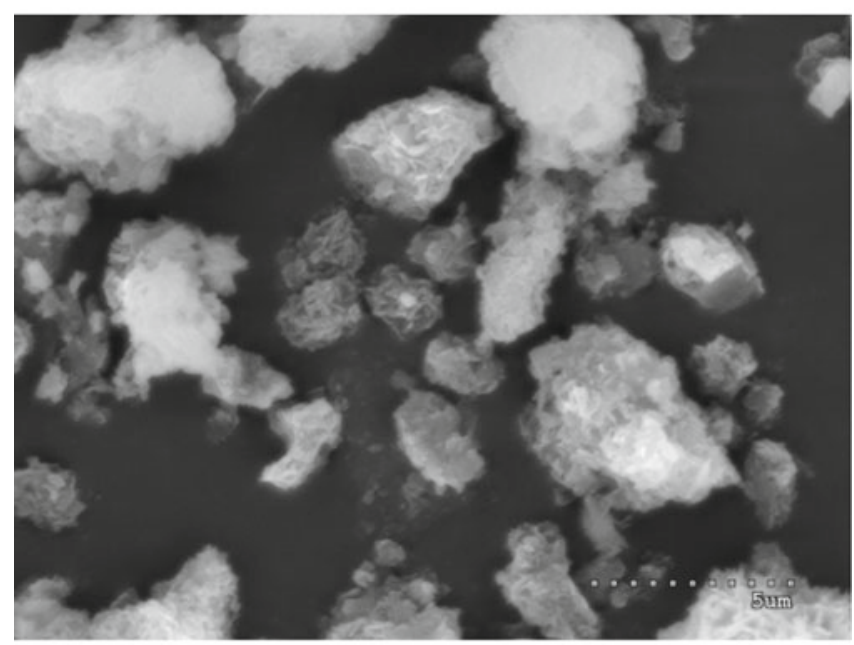

C

Figure 1. Scanning electron micrographs of the silica from Piotrowice before functionalization (A) and the silica functionalized with $1 \%$ (B) and $5 \%$ of silanes (C)

particles does not change. The raw silica from Piotrowice contains significant amounts of impurities, including iron (Fig. 2A). Therefore, it was purified with hydrochloric acid water solution to remove or reduce the adsorbed components (Fig. 2B).

The silica after silanization was characterized by FTIR spectroscopy (Fig. 3) in order to confirm the chemical bonding of the silanes on the material surface. A broad band at about $3450 \mathrm{~cm}^{-1}$ was assigned to the $\mathrm{OH}$ stretching vibrations. The broad and intense band at $1117 \mathrm{~cm}^{-1}$ was assigned to the siloxane vibration, while the bands at 796 and $481 \mathrm{~cm}^{-1}$ were assigned to the Si-O-Si stretching and $\mathrm{Si}-\mathrm{O}-\mathrm{Si}$ bending, respectively. The band appearing at $1643 \mathrm{~cm}^{-1}$ was attributed to angular vibrations of water molecule. As a consequence of the reaction with silane coupling agents, the following bands appeared: around $2900 \mathrm{~cm}^{-1}$ (CH stretching vibrations of alkyl groups), $1573 \mathrm{~cm}^{-1}$ (bending vibrations of $\mathrm{NH}_{2}$ ) and $1470 \mathrm{~cm}^{-1}$ (bending vibrations of $\mathrm{CH}_{2}$ groups) ${ }^{20}$. Unfortunately, it was difficult to confirm the presence of $\mathrm{SH}$ group. Therefore, sulfur presence in the functionalized materials was confirmed by XRF analysis (Fig. 2C). The amount of organic ligands attached to the silica surface was estimated on the basis of elemental analysis. The bifunctional sorbents contain either $0.089 \%$ nitrogen $(\mathrm{N})$ and $0.076 \%$ sulfur $(\mathrm{S})$ or $0.365 \% \mathrm{~N}$ and $0.403 \% \mathrm{~S}$. It could be calculated that $1 \mathrm{~g}$ of the silica contains about $0.01 \mathrm{~g}$ or $0.05 \mathrm{~g}$ functional groups, thus henceforth the term of the silica functionalized with 1 or $5 \%$ of silanes will be used.

\section{Sorption properties of the materials studied}

According to the Tessier sequential analysis, the metals studied were extracted to five fractions: $F_{1}$ exchangeable; $\mathrm{F}_{2}$ bound to carbonates; $\mathrm{F}_{3}$ bound to iron and manganese oxides; $\mathrm{F}_{4}$ bound to organic matter and $\mathrm{F}_{5}$ residual. The sequential analysis experiments were performed three times and the average values were taken. Each soil sample was analyzed after 4 and 30 days in order to determine the effect of soil environment on the stability of the materials used. Preliminary studies were used for determination of concentrations of heavy metals and arsenic in the soil sample. The total content of heavy metals and arsenic in the soil was $298.25 \pm 18.65$ $\left[\mathrm{mg} \mathrm{kg}^{-1}\right]$ of cooper, $117.04 \pm 8.09\left[\mathrm{mg} \mathrm{kg}^{-1}\right]$ of lead, $112.87 \pm 6.74\left[\mathrm{mg} \mathrm{kg}^{-1}\right]$ of zinc, $2.17 \pm 0.04\left[\mathrm{mg} \mathrm{kg}^{-1}\right]$ of cadmium and $9.87 \pm 1.22\left[\mathrm{mg} \mathrm{kg}^{-1}\right]$ of arsenic. Figure 4 presents the average concentration of $\mathrm{Cu}$ (Fig. 4A), $\mathrm{Pb}$ (Fig. 4B), Zn (Fig. 4C), Cd (Fig. 4D) and As (Fig. 4E) in fractions $F_{1}-F_{5}$ before and after addition of different amounts of non-functionalized and functionalized silica Piotrowice after 4 days. The highest content of $\mathrm{Cu}, \mathrm{Pb}$ and $\mathrm{Zn}$ in reference sample " 0 " was in fraction $\mathrm{F}_{3}$, while $\mathrm{Cd}$ and $\mathrm{As}-$ in fraction $\mathrm{F}_{5}$. Further research was carried out with respect to these contents.

In the first stage, the effect of unmodified silica on the presence of metals in individual fractions was tested. The addition of $4 \%$ (sample 1a) or $10 \%$ (sample 1b) of silica did not affect significantly the concentration of metals in individual fractions and the highest content of individual elements appeared in the same fractions as in the soil. Thus, the highest copper content was observed in fraction $\mathrm{F}_{3}$ and accounted for approximately $40 \%$ of the total amount of this metal in the soil. The percentage contents of lead and zinc in $\mathrm{F}_{3}$ was very similar for samples $0,1 \mathrm{a}$ and $1 \mathrm{~b}$ (about $38 \%$ of the total content of each element in the soil). The percentages for these metals in fraction $\mathrm{F}_{5}$ were as follows: $23 \%(\mathrm{Cu}), 24 \%$ $(\mathrm{Pb})$ and $36 \%(\mathrm{Zn})$. The situation is slightly different for cadmium and arsenic. The highest concentration of both elements was observed in fraction $\mathrm{F}_{5}$ and were 


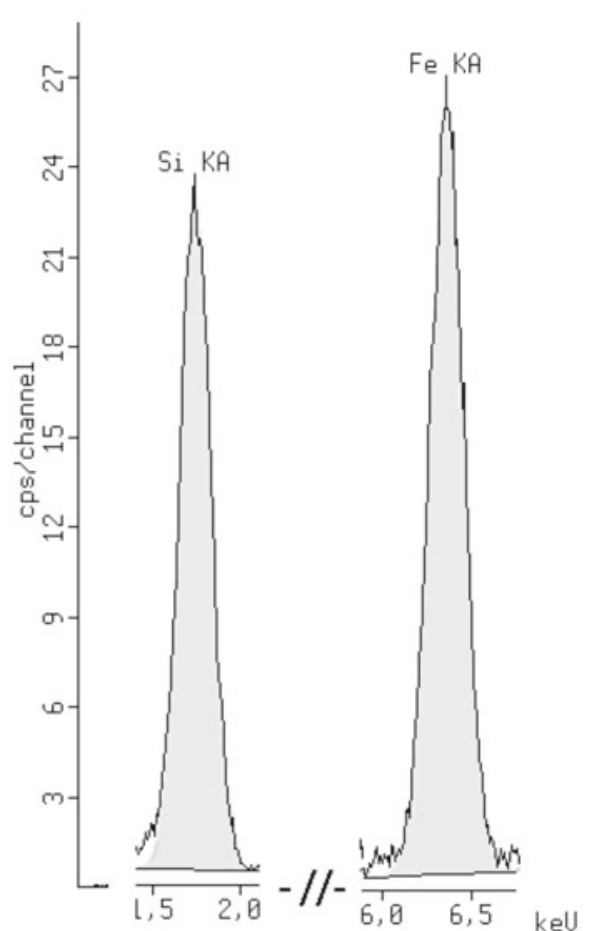

a)

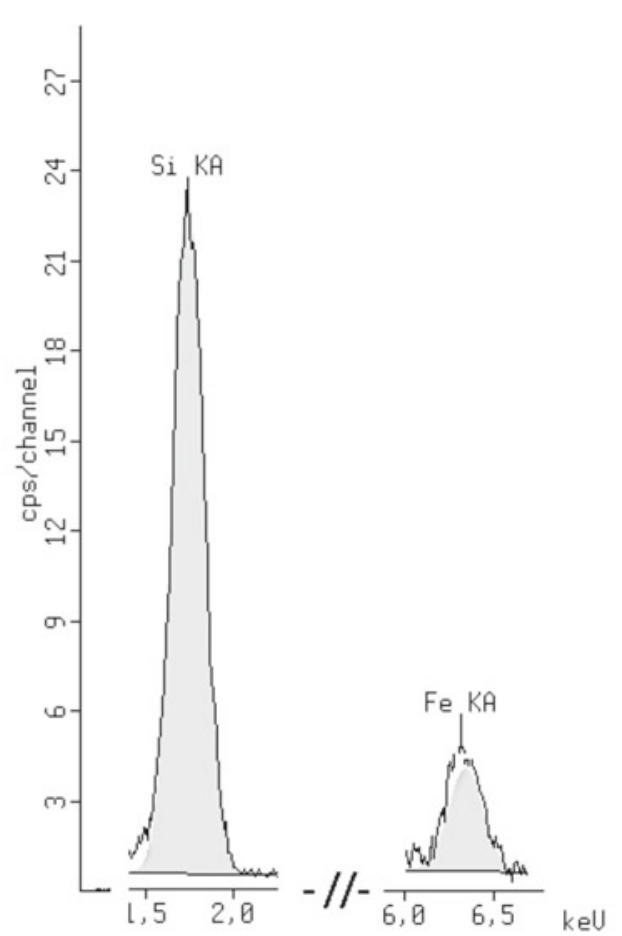

b)

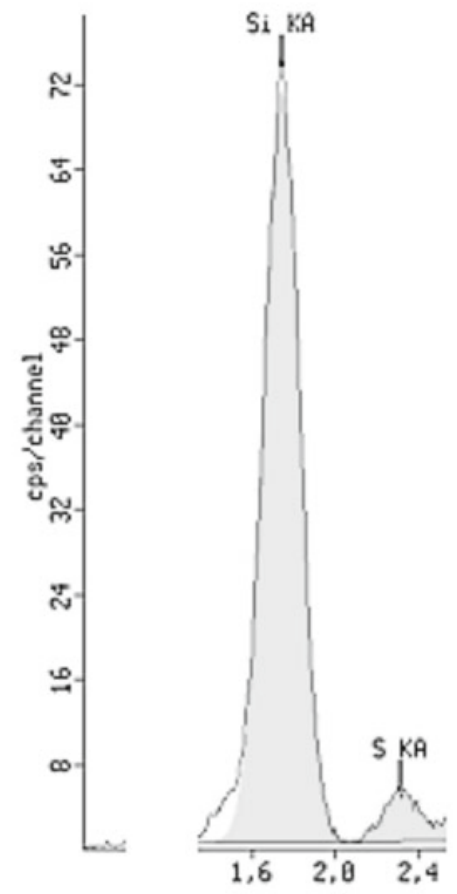

c)

Figure 2. The X-ray fluorescence spectra of the silica before (A) and after activation with hydrochloric acid water solution (B), and the silica functionalized with $1 \%$ of silanes (C)

of $35 \%$ or $40 \%$ respectively of the total content. After addition of an inorganic silica a slight increase of their concentration in the last fraction was observed. Thus for samples $1 \mathrm{a}$ and $1 \mathrm{~b}$, the percentage of cadmium and arsenic $\mathrm{F}_{5}$ was $40 \%$ (Cd) and $42 \%$ (As).

Significant changes were noted upon introduction of functionalized silica in the soil. In all samples, the highest concentration of metals was observed in the fraction inaccessible for plants $\left(\mathrm{F}_{5}\right)$. Significant differences could already be seen after $4 \%$ addition of the silica functionalized with $1 \%$ of silanes. The concentration of monitored elements was visibly reduced in the fractions $\mathrm{F}_{1}-\mathrm{F}_{4}$, thereby leading to their higher contents in the residual fraction in amounts by about $50 \%$ higher relative to the initial content. In case of cooper the percentage in the fraction unavailable to plants did not exceed $50 \%$ of the total amount (44\%). However, the concentration of $\mathrm{Cu}$ in the samples studied was much higher than the other elements. For other impurities, the percentage in $\mathrm{F}_{5}$ increased to $50(\mathrm{~Pb}), 66(\mathrm{Zn}), 75$ (Cd) and 69 (As) \%.

The higher amount $(10 \%)$ of the silica functionalized with $1 \%$ of silanes resulted in further drop in the metal content in $\mathrm{F}_{1}-\mathrm{F}_{4}$, however it was no longer so rapid. For example, after the extraction fraction $\mathrm{F}_{1}$ contained $24.54 \pm 1.63\left[\mathrm{mg} \mathrm{kg}^{-1}\right]$ of $\mathrm{Cu}$ (which corresponds to about $8 \%$ of the total content), while after addition of $4 \%$ of the sorbent containing $1 \%$ of silanes the same fraction contained - only $14.00 \pm 1.12\left[\mathrm{mg} \mathrm{kg}^{-1}\right](4.7 \%$ of the total content); and after addition of $10 \%$ of the sorbent the same fraction contained - $10.80 \pm 1.11\left[\mathrm{mg} \mathrm{kg}^{-1}\right](3.6 \%$ of the total content). Such trend is maintained for the rest of fractions and metals. Consequently, an increase in the concentration of the elements monitored in fraction $\mathrm{F}_{5}$ does not exceed $4 \%$.
Very similar results were obtained upon addition of $4 \%$ of the silica functionalized with $5 \%$ of silane. Further changes, resulting in an increase in metal concentration in the fraction inaccessible to plants, could be seen with increased addition of this sorbent (10\%). However, an increase in content of heavy metals and arsenic in fraction $\mathrm{F}_{5}$ was within 4 percent.

Finally, the content of metals unavailable for the plants increased in relation to that in the soil sample without functionalized silica: from $67.64 \pm 3.05$ to $155.20 \pm 7.13$ $\left[\mathrm{mg} \mathrm{kg}^{-1}\right.$ ] for copper (from 23 to $52 \%$ of the total content), from $28.10 \pm 0.94$ to $77.03 \pm 2.87\left[\mathrm{mg} \mathrm{kg}^{-1}\right]$ for lead (from 24 to $66 \%$ of the total content), from $41.60 \pm 2.17$ to $82.83 \pm 3.49\left[\mathrm{mg} \mathrm{kg}^{-1}\right]$ for zinc (from 36 to $73 \%$ of the total content), from $0.77 \pm 0.01$ to $1.82 \pm 0.02[\mathrm{mg}$ $\mathrm{kg}^{-1}$ ] for cadmium (from 35 to $84 \%$ of the total content) and from $3.96 \pm 0.14$ to $7.59 \pm 0.39\left[\mathrm{mg} \mathrm{kg}^{-1}\right]$ for arsenic (from 40 to $77 \%$ of the total content).

Moreover, it is extremely important that the results obtained after 30 days practically do not differ from

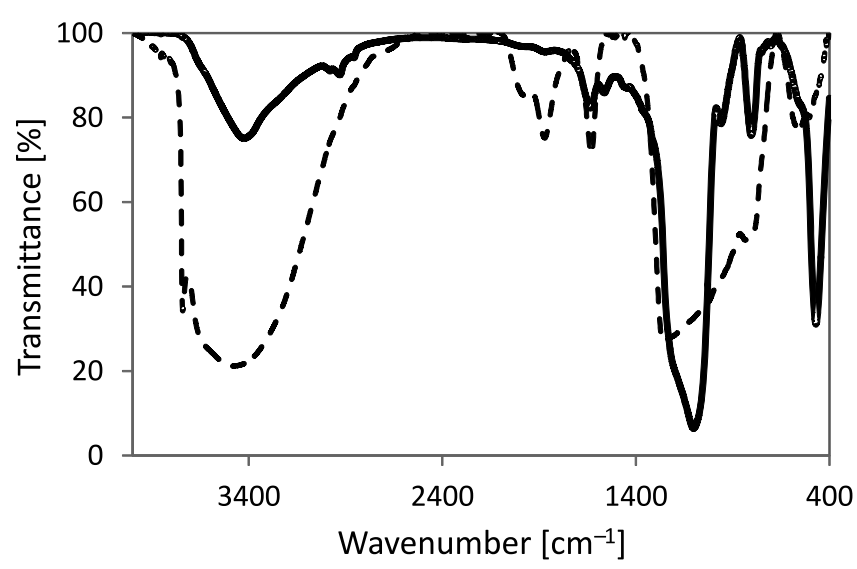

Figure 3. FTIR spectrum of the silica before (-----) and after ) functionalization with silanes 


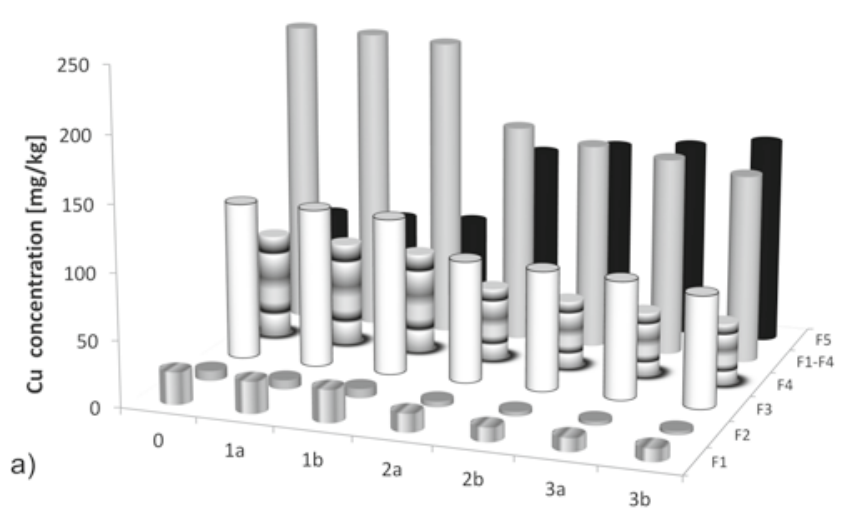

\begin{tabular}{|l|l|}
\hline No & Abbreviation \\
\hline 0 & Soil without any addition \\
\hline 1a & Soil with $4 \%$ of purified silica Piotrowice \\
\hline 1b & Soil with $10 \%$ of purified silica Piotrowice \\
\hline 2a & Soil with $4 \%$ of functionalized silica Piotrowice $(1 \%)$ \\
\hline $2 \mathrm{~b}$ & Soil with $10 \%$ of functionalized silica Piotrowice $(1 \%)$ \\
\hline 3a & Soil with $4 \%$ of functionalized silica Piotrowice $(5 \%)$ \\
\hline 3b & Soil with $10 \%$ of functionalized silica Piotrowice $(5 \%)$ \\
\hline F1-F5 & Fractions $\mathrm{F}_{1}-\mathrm{F}_{5}$ \\
\hline
\end{tabular}
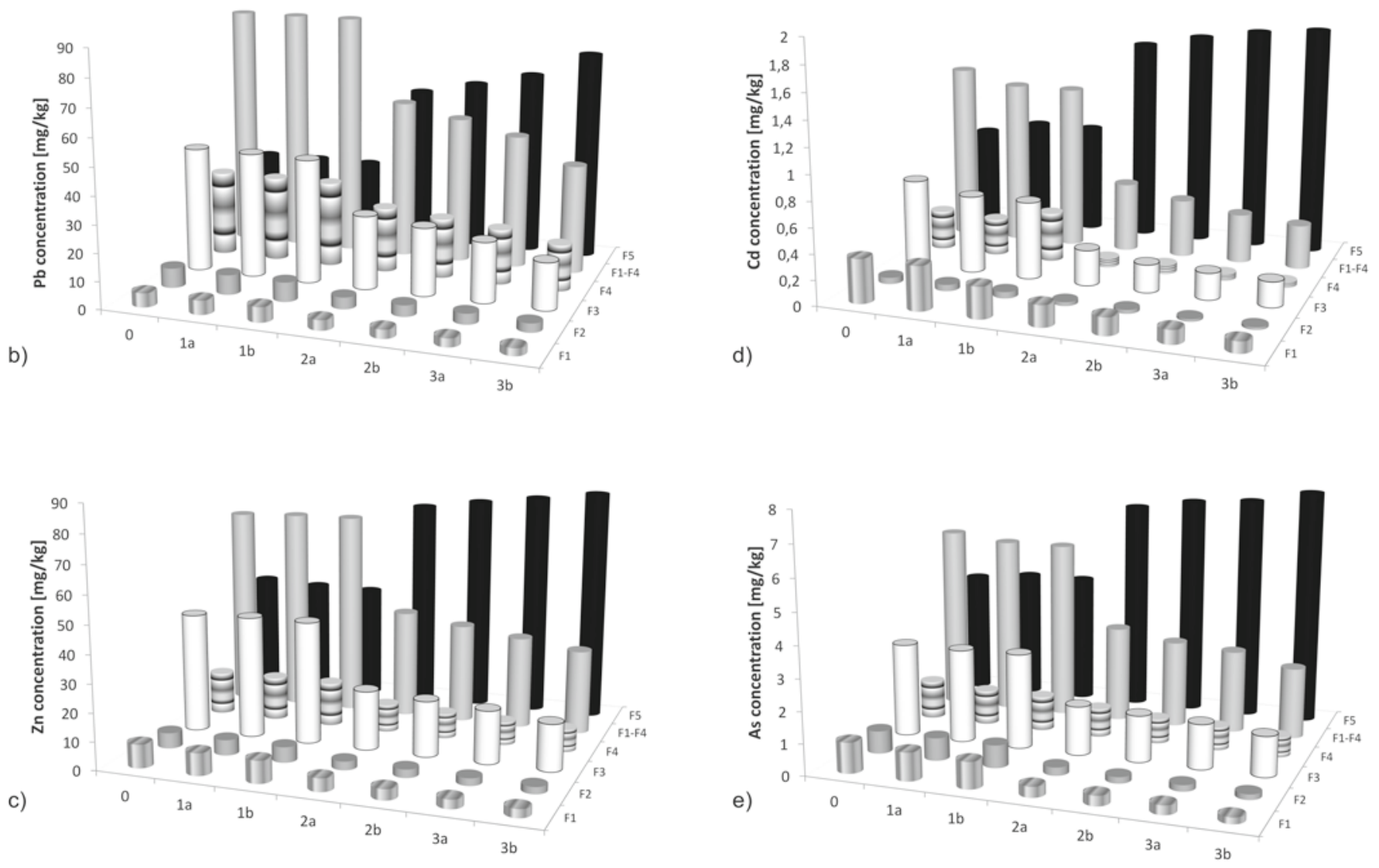

Figure 4. Concentration of cooper (A), lead (B), zinc (C), cadmium (D) and arsenic (E) in fractions of Tessier sequential analysis, where: 0 - soil without any addition, $1 \mathrm{a}$ - soil with $4 \%$ of purified silica Piotrowice, $1 \mathrm{~b}$ - soil with $10 \%$ of purified silica Piotrowice, $2 \mathrm{a}$ - soil with $4 \%$ of functionalized silica Piotrowice (1\%), $2 \mathrm{~b}$ - soil with $10 \%$ of functionalized silica Piotrowice (1\%), $3 \mathrm{a}$ - soil with $4 \%$ of functionalized silica Piotrowice (5\%), $3 \mathrm{~b}$ - soil with $10 \%$ of functionalized silica Piotrowice (5\%), F1-F5 - fractions $\mathrm{F}_{1}-\mathrm{F}_{5}$

the values obtained after 4 days (difference of 2-3\%). Firstly, it proves that organic layer at the silica surface is very stable under soil conditions. Furthermore, the release of heavy metals requires concentrated nitric acid, so the presence of such complexes in the soil does not pose a risk of their accidental release as a result of contact with the eluent.

The content of all metals studied in residual fraction $\mathrm{F}_{5}$ in the soil samples was found to increase with increasing content of silanes in functionalized silica (1 or $5 \%$ of silanes), in relation to that in the soil sample without any material added or with raw silica, which can be concluded from EDX images (Fig. 5). The areas containing nuclei of elements of high atomic number are mapped as the lighter and the areas containing nuclei of elements with low atomic numbers as darker.

The results clearly indicate that the factor responsible for the binding of heavy metals and arsenic are organic compounds attached to the silica surface. Incorporation of functional groups - triamine and thiol - determines the permanent metal complexation, and thus prevents the uptake of these metals by plants. Increased amount of the sorbent or increased percentage of the organic layer on the inorganic matrix cause further loss of harmful elements in the form available to plants. It is due to the increase in the number of free functional groups responsible for the metal binding. In our studies we used a material with a small amount of the organic layer ( 1 or 5 percent) in relation to the inorganic matrix. 


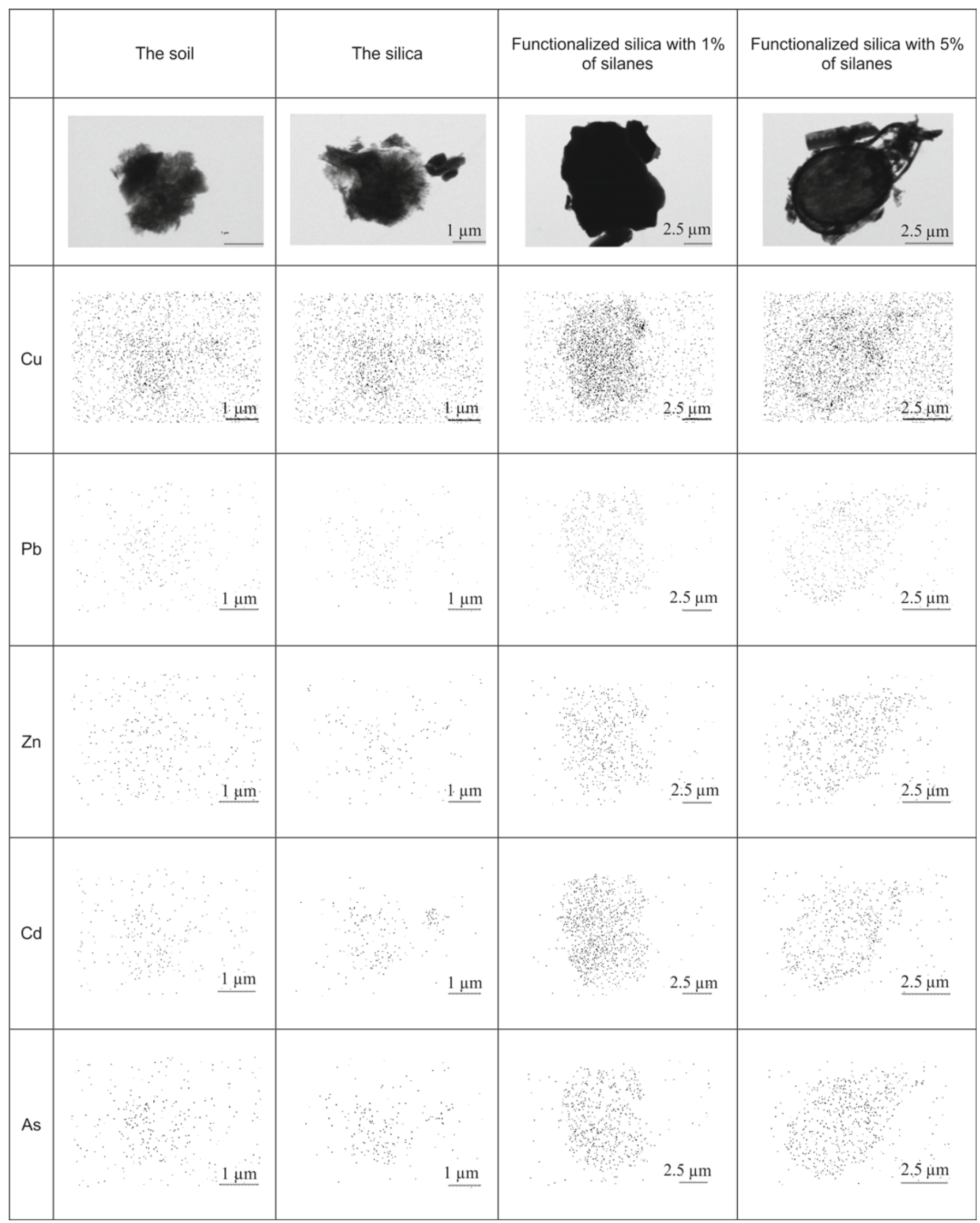

Figure 5. Transmission electron microscope and selected element $(\mathrm{Cu} ; \mathrm{Pb} ; \mathrm{Zn} ; \mathrm{Cd} ; \mathrm{As})$ distribution images for the soil samples studied after extraction of fractions $\mathrm{F}_{1}-\mathrm{F}_{4}$

Such a procedure aimed to minimize cost of a resulting sorbent. Hybrid materials based on silica usually contain about $1 \mathrm{mmol}$ of functional groups per 1 gram of an inorganic matrix. In case of simple silanes it corresponds to about 20 percentage of surface coverage. Therefore we assume that greater number of surface functional groups would result in an increase in efficiency of the sorbents.

\section{CONCLUSIONS}

The paper presents a method to limit the availability, and therefore assimilation of heavy metals and arsenic 
by plants, in the areas under the impact of the copper smelter. The method proposed involves the use of cheap silica extracted from a Polish mine, subjected to initial activation and a simple functionalization by two organic silanes. The presence of functional groups (amine and thiol) resulted in an effective and significant bonding of harmful ingredients in the form inaccessible to plants. Availability of the raw material applied, low cost, effectiveness and stability of the proposed inorganic-organic sorbent make this method apt to practical use in agricultural areas contaminated with harmful metals to restore these lands to crop growing.

\section{ACKNOWLEDGEMENTS}

The authors would like to thank The National Science Center of Poland (Grant No. 2011/03/B/ST5/01573) for financial support.

\section{LITERATURE CITED}

1. Krämerm, U., Talke, I.N. \& Hanikenne, M. (2007). Transition metal transport. Fed. Eur. Biochem. Soc. Lett. 581, 2263-2272. DOI: 10.1016/j.febslet.2007.04.010.

2. Dube, A., Zbytniewski, R., Kowalkowski, T., Cukrowska, E. \& Buszewski, B. (2011). Adsorption and Migration of Heavy Metals in Soil Reviews. Pol. J. Environ. Stud. 10, 1-10.

3. Jadia, C.D. \& Fulekar, M.H. (2009). Phytoremediation of heavy metals. Recent techniques. Afr. J. Biotechnol. 8, 921-928. DOI: 0.5897/AJB2009.000-9152.

4. Allaway, W.H. (1968). Agronomic control over the environmental cycling of trace elements. Adv. Agron. 20, 235-274. DOI: $10.1016 / \mathrm{S} 0065-2113(08) 60858-5$.

5. Baker, W.G. (1972). Toxicity levels of mercury lead. copper and zinc in tissue culture systems of cauliflowers lettucepotato and carrot. Can. J. Bot. 50, 973-976. DOI: 10.1139/b72-117.

6. Nagajyoti, P.C., Lee, K.D. \& Sreekanth, T.V.M. (2010). Heavy metals occurrence and toxicity for plants: A review. Environ. Chem. Lett. 8, 199-216. DOI: 10.1007/s10311-010-0297-8.

7. Kabata-Pendias, A. (2011). Trace Elements in Soils and Plants (4th ed.). Taylor and Francis Group, Boca Raton, USA. ISBN 978-1-4200-9368-1.

8. El-Nahhal, I.M., Zaggout, F.R. \& El-Ashgar, N.M. (2000). Uptake of Divalent Metal Ions $\left(\mathrm{Cu}^{2+}, \mathrm{Zn}^{2+}\right.$ and $\left.\mathrm{Cd}^{2+}\right)$ by Polysiloxane Immobilized Monoamine Ligand System. Anal. Lett. 33, 2031-2053. DOI:10.1080/00032710008543173.

9. Li, S., Yue, X., Jing, Y., Bai, S. \& Dai, Z. (2011). Fabrication of zonal thiol-functionalized silica nanofibers for removal of heavy metal ions from wastewater. Colloid Surf. A Phys. Chem. Eng. Asp. 380, 229-233. DOI: 10.1016/j.colsurfa.2011.02.027.

10. Burke, A.M., Hanrahan, J.P., Healy, D.A., Sodeau, J.R., Holmes, J.D. \& Morris, M.A. (2009). Large pore bifunctionalised mesoporous silica for metal ion pollution treatment. J. Hazard. Mater. 164, 229-234. DOI: 10.1016/j. jhazmat.2008.07.146.

11. Boyaci, E., Çağır, A., Shahwan, T. \& Eroğlu, A.E. (2011). Synthesis, characterization and application of a novel mercapto- and amine-bifunctionalized silica for speciation/sorption of inorganic arsenic prior to inductively coupled plasma mass spectrometric determination. Talanta 85, 1517-1525. DOI: 10.1016/j.talanta.2011.06.021.

12. Kurczewska, J. \& Schroeder, G. (2010). Copper removal by carbon nanomaterials bearing cyclam-functionalized silica. Cent. Eur. J. Chem. 8, 341-346. DOI: 10.2478/s11532-009-0131-y.

13. Kurczewska, J. \&, Schroeder G. (2010). Silica surface modified by aliphatic amines as effective copper complexing agents. Inter. J. Mater. Res. 101, 1037-1041. DOI: 10.3139/146.110372.
14. Kurczewska, J. \& Schroeder, G. (2010). Synthesis of silica chemically bonded with poly(ethylene oxide) 4-arm, amine-terminated for copper cation removal. Water Environ. Res. 82, 2387-2392. DOI: 10.2175/106143010X12780288628011.

15. Kurczewska, J. \& Schroeder, G. (2013). Epoxy resin modified with amine as an effective complexing agent of metal cations. Cent. Eur. J. Chem. 11, 1723-1728. DOI: 10.2478/ s11532-013-0308-2.

16. Grzesiak, P., Łukaszyk, J., Grobela, M., Kurczewska, J. \& Schroeder, G. (2013). Binding of heavy metals and arsenic in soil with N1-(trimethoxysilylpropyl)-diethylenetriamine. Przem. Chem. 92, 2115-2118.

17. Grzesiak, P., Łukaszyk, J., Schroeder, G. \& Kurczewska, J. (2013). Remediation of heavy metals from soil using quartz sand functionalized with organic amino silanes. Pol. J. Chem. Technol. 15, 116-120. DOI: 10.2478/pjct-2013-0079.

18. Schroeder, G. \& Kurczewska, J. (2014). Chemistry for nanotechnology. Pol. J. Chem. Technol. 16, 70-74. DOI: 10.2478/ pjct-2014-0012.

19. Tessier, A., Campbell, P.G. \& Bission, M. (1979). Sequential Extraction Procedure for the Speciation of Particulate Trace Metals. Anal. Chem. 51, 844-851. DOI: 10.1021/ac50043a017.

20. Pretsch, E., Buhlmann, P. \& Badertscher, M. (2009). Structure Determination of Organic Compounds (4th ed.). SpringerVerlag Berlin Heidelberg, DOI: 10.1007/978-3-540-93810-1. 